\title{
Base-induced Cyclisation of ortho-Substituted 2-Phenyloxazolines to Give 3-Aminobenzofurans and Related Heterocycles
}

R. Alan Aitken*

Andrew D Harper

Alexandra M. Z. Slawin

EaStCHEM School of Chemistry, University of St Andrews, North Haugh, St Andrews, Fife, KY16 9ST, U.K.

raaest-and.ac.uk
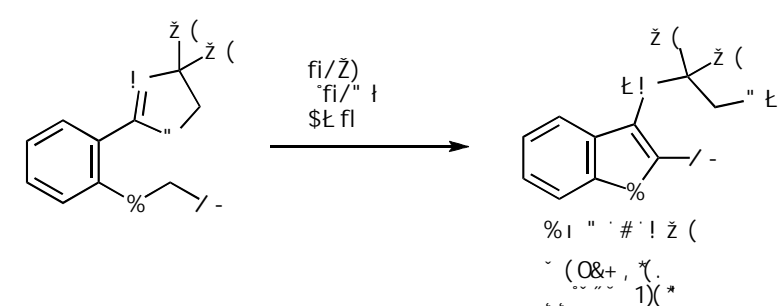

\begin{abstract}
Received:
Accepted:
Published online:
DOI: Abstract Treatment of orthobenzyloxyphenyloxazolines with butyllithium and potassium $t$-butoxide results in cyclisation with ring-opening of the oxazoline to give 2-aryl-3aminobenzofurans. The reaction also occurs with the corresponding benzylthio- and benzylamino-compounds to give benzothiophenes and indoles, respectively. Use of an ortho-allyloxyphenyloxazoline gives the corresponding 2-vinylbenzofuran, while both $\alpha$ methylbenzyloxy and benzylsulfonyl compounds form stable spirooxazolidine products. The X-ray structure of an aminobenzothiophene product has been determined.

Key words cyclisation, oxazoline, benzofuran, benzothiophene, indole, schlosser's base, spiro heterocycle
\end{abstract}

Although the chemistry of 4,5-dihydrooxazoles (2-oxazolines) has been extensively developed over the last 40 years, ${ }^{1-3}$ new useful reactions facilitated by this auxiliary group continue to be discovered. We have recently examined the ability of this group to facilitate the [1,2]-Wittig rearrangement of an adjacent benzyl ether in compounds such as $\mathbf{1}$ and the success of this strategy will be reported elsewhere. However, in the course of this work, it was discovered that treatment of $\mathbf{1}$ with both $n$-butyllithium and potassium $t$-butoxide ("Schlosser's base") resulted in unexpected cyclisation with ring opening of the oxazoline to give the 3 -aminobenzofuran $\mathbf{3}$ in high yield. ${ }^{4}$ Optimisation of the process is shown in Table 1 . While the Wittig rearrangement product $\mathbf{2}$ was formed using BuLi in THF, 2.2 equivalents were required to obtain a good yield and this gave $\mathbf{3}$ as a major byproduct. Most other solvents gave mixtures with lower selectivity for $\mathbf{2} v s$. 3 and the only two that gave complete reaction, MTBE and toluene, actually favoured the debenzylation product 4 . Better selectivity for $\mathbf{3}$ was obtained using the BuLi / $\mathrm{t}$-BuOK mixture but 1.1 equivalents
Table 1 Optimisation of the reaction for formation of 3<smiles>CC1(C)COC(c2ccccc2OCc2ccccc2)=N1</smiles><smiles>CC(C)(CO)Nc1c(-c2ccccc2)oc2ccccc12</smiles>

4

\begin{tabular}{|c|c|c|c|c|}
\hline \multirow{2}{*}{ Conditions } & \multicolumn{4}{|c|}{ Ratio of products ( $\%$ ) } \\
\hline & 1 & 2 & 3 & 4 \\
\hline 1.1 eq. BuLi, THF & 57 & 29 & 8 & 6 \\
\hline 1.1 eq. $\mathrm{NaH}, \mathrm{THF}$ & 100 & 0 & 0 & 0 \\
\hline 2.2 eq. BuLi, THF & 0 & 75 & 19 & 6 \\
\hline 2.2 eq. BuLi, $E t_{2} \mathrm{O}$ & 13 & 38 & 39 & 10 \\
\hline 2.2 eq. BuLi, t-BuOMe & 0 & 24 & 27 & 49 \\
\hline 2.2 eq. BuLi, 2-MeTHF & 39 & 47 & 6 & 8 \\
\hline 2.2 eq. BuLi, dioxane & 4 & 64 & 19 & 13 \\
\hline 2.2.eq. BuLi, DME & 42 & 17 & 30 & 11 \\
\hline 2.2 eq. BuLi, PhMe & 0 & 13 & 29 & 58 \\
\hline 1.1.eq. BuLi, t-BuOK, THF & 57 & 4 & 33 & 6 \\
\hline 2.2 eq. BuLi, t-BuOK, THF & 17 & 0 & 79 & 4 \\
\hline 3.3 eq. BuLi, t-BuOK, THF & 3 & 0 & 95 & 2 \\
\hline
\end{tabular}

gave mostly starting material and it was only with just over 3 equivalents that high conversion with excellent selectivity for $\mathbf{3}$ was achieved (Scheme 1). We interpret this in terms of the mechanism shown in Scheme 2 where initial ortho-metallation is followed by deprotonation of the benzyl group allowing equilibration with cyclised forms, but it is only the third deprotonation leading to formation of the aromatic furan ring that decisively leads to product $\mathbf{3}$. 


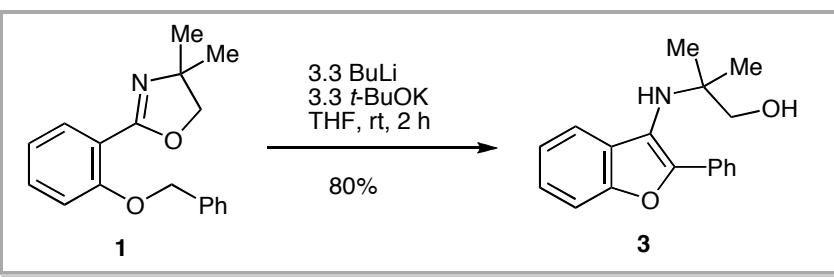

Scheme 1 Optimised conditions for cyclisation of 1 to give 3 .

As far as we are aware, the only previous examples of intramolecular base-induced cyclisation of a carbanion onto an oxazoline resulting in ring-opening of the latter are a single example of naphtho[2,3-b]thiophene formation upon treatment of a 1-bromo-2-naphthyloxazoline with the sodium salt of 4-chlorobenzylmercaptan, 5 and two reports in which fluorenone products are formed as byproducts in treatment of an ortho-lithiated phenyloxazoline with an aryne.6,7 The current process does bear a close resemblance to the Gewald reaction, ${ }^{8}$ in which an ortho-alkoxybenzonitrile is treated with base leading to a 3-aminobenzofuran. Although this process originally required a strongly electron-withdrawing substituent on the alkoxy group, more recent examples show that it also works with less stabilised anions, ${ }^{9-11}$ including the cyclisation of 2-benzyloxy-3-cyanopyridine. ${ }^{12}$ It might also be<smiles>[M]CC(C)(C)N=C1c2c([M])cccc2OC1c1ccccc1</smiles>

Scheme 2 Proposed mechanism for conversion of 1 into 3.<smiles>CC1(C)COC(c2ccccc2O)=N1</smiles>

4<smiles>CC1(C)COC(c2ccccc2OC[Al])=N1</smiles>

5

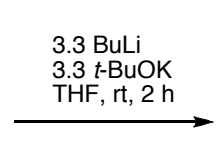<smiles>[C]C(C)(CO)Nc1c([Al])oc2ccccc12</smiles>

6<smiles>COc1ccc(-c2oc3ccccc3c2NC(C)(C)C(C)(C)C)cc1</smiles>

6a $12 \%$

6b $66 \%$<smiles>COc1cccc(-c2oc3ccccc3c2NC(C)(C)C)c1</smiles><smiles>COc1ccccc1-c1oc2ccccc2c1NC(C)(C)CO</smiles>

6d $11 \%$<smiles>COc1ccc2ccccc2c1-c1oc2ccccc2c1NC(C)(C)CO</smiles>

$6 e 47 \%$<smiles>Cc1ccc(C(=O)Oc2ccccc2C(=O)NC(C)(C)C)cc1</smiles>

Scheme 3 Preparation of compounds $5 \mathbf{a}-\mathbf{j}$ and their reaction to give $6 \mathbf{a}-\mathbf{e}$ and $7 \mathbf{a}, \mathbf{b}$

mentioned that heterocycle formation by intramolecular cyclisation of both alkoxide ${ }^{13}$ and imide $^{14}$ anions onto 2oxazolines are well known, giving phthalides and isoquinolines respectively after hydrolysis. There are relatively few direct cyclization routes to 3 -aminobenzofurans but one notable recent method involves treatment of 2-alkynylphenols with $O$ benzoylhydroxylamines and a copper catalyst under basic 
conditions, although this was only used to obtain 3-dialkylamino products. ${ }^{15,16}$

Although the starting oxazoline $\mathbf{1}$ was readily prepared by conventional step-wise construction of the oxazoline ring with the benzyl group already in place, a range of examples with substituted benzyl groups were more conveniently synthesised from the phenol 4, itself derived from dealkylation of the allyl compound 12 (vide infra). In this way compounds $\mathbf{5 a - j}$ were prepared and characterised (Scheme 3).

When these were subjected to the conditions of Scheme 1, a varied pattern of reactivity was observed. Compounds $\mathbf{5 a - e}$ all gave the expected benzofurans 6a-e in moderate to low yield with the latter being caused by extensive decomposition during chromatographic purification. In the case of $\mathbf{5 f}$ and $\mathbf{5 g}$, the products isolated were those of oxidative cleavage of the benzofuran ring, $\mathbf{7 a}$ and $\mathbf{7 b}$, and it is likely that similar 2benzoyloxybenzamides were also formed in many of the other cases. The ready oxidative $\mathrm{C} 2-\mathrm{C} 3$ bond cleavage of a 3hydroxybenzofuran was noted as early as $1916,{ }^{17}$ and the same process has been reported more recently for 2,3diaminobenzofurans. ${ }^{18}$ For the nitro-containing compounds $\mathbf{5 h}$ $\mathbf{j}$, base treatment resulted in extensive decomposition and no useful products were obtained.

The oxazolines $\mathbf{8}$ and $\mathbf{1 0}$ with secondary alkoxy groups were readily prepared by alkylation of $\mathbf{4}$ and also underwent cyclisation. The products were, respectively, the spiro oxazolidine 9 obtained as a 5:3 mixture of diastereomers and the dihydrobenzofuran-3-imine $\mathbf{1 1}$ (Scheme 4). The potential of chiral oxazoline analogues of $\mathbf{8}$ for the synthesis of 2-chiral benzofuran-3-ones is currently being investigated.

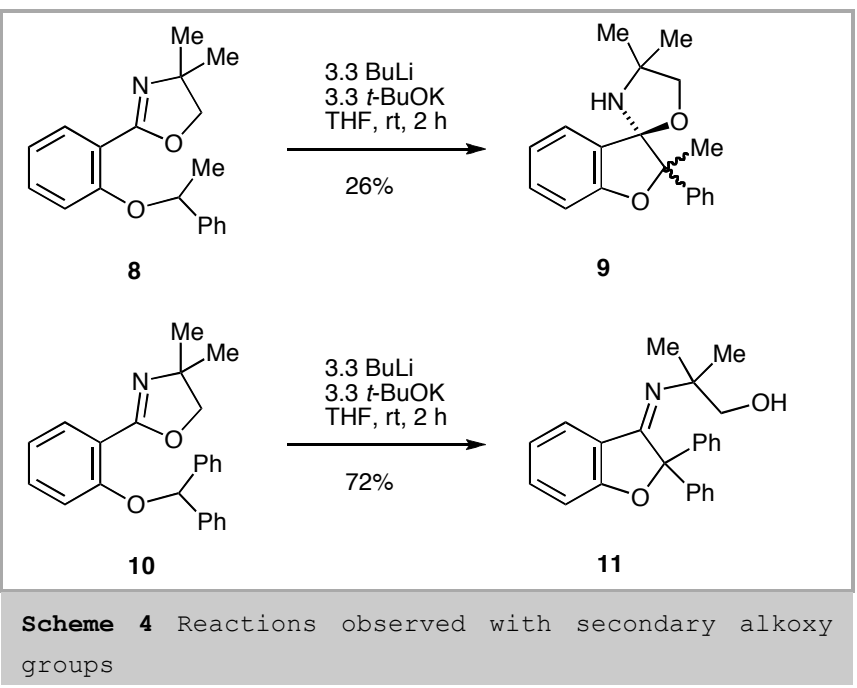

The 2-allyloxyphenyloxazoline $\mathbf{1 2}$ was also found to undergo the same process giving the 2-vinylbenzofuran 13 (Scheme 5). While we were unable to get this to react as a diene with a wide range of dienophiles, it did undergo a Diels Alder reaction as the dienophile with tetrachlorothiophene dioxide ${ }^{19}$ with extrusion of $\mathrm{SO}_{2}$ to give adduct 14 .

A most useful observation was that by changing the reaction solvent to toluene, treatment of $\mathbf{1 2}$ with just over two equivalents of $\mathrm{BuLi} / \mathrm{KOBu}^{\mathrm{t}}$ gave the phenol $\mathbf{4}$ in high yield, presumably with elimination of hept-1-ene and this was the method used to obtain $\mathbf{4}$ for synthesis of $\mathbf{5 a - j , ~} 8$ and $\mathbf{1 0}$, effectively using $O$-allyl as a protecting group through the oxazoline formation.<smiles>C=CCOc1ccccc1C1=NC(C)(C)CO1</smiles>

The method is also applicable to formation of 3aminobenzothiophenes from 2-(benzylthio)phenyloxazolines and conversion of $\mathbf{1 5}$ into $\mathbf{1 6}$ proceeded in good yield with 2.5 equivalents of $\mathrm{BuLi} / \mathrm{KOBu}^{\mathrm{t}}$ (Scheme 6). The structure of product 16 was confirmed by X-ray diffraction, which also showed an interesting pattern of hydrogen bonding involving the amino alcohol function. ${ }^{20}$ The sulfide $\mathbf{1 5}$ was oxidised to both the sulfoxide $\mathbf{1 7}$ and the sulfone $\mathbf{1 8}$ using standard methods and, in the latter case, there was partial breakdown of the oxazoline to give the nitro ester 19 as a byproduct. This is a known reaction of oxazolines with mCPBA. ${ }^{21}$ Base treatment of the sulfoxide $\mathbf{1 7}$

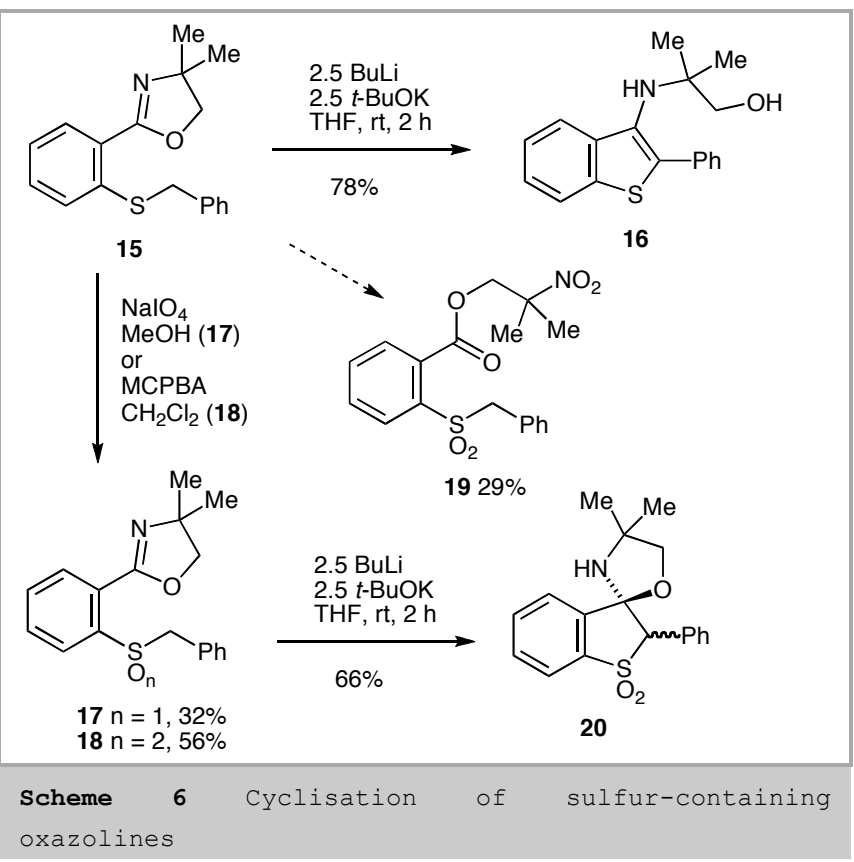

led to extensive decomposition and gave no useful products while the sulfone 18 reacted cleanly to give the spiro compound 20 as a 3:2 mixture of diastereomers. The formation of 3- 
aminobenzothiophenes by the base-induced cyclisation of 2 (benzylthio)benzonitrile as well as the corresponding sulfoxide and sulfone has been reported, ${ }^{22}$ and there are numerous other reports of Gewald-type benzothiophene formation ${ }^{11,23-27}$ but, apart from the example already mentioned, ${ }^{5}$ none involving cyclisation onto an oxazoline.

Finally the method was extended to indole formation. The oxazoline $\mathbf{2 1}$ was prepared by nucleophilic substitution of the 2 methoxyphenyloxazoline 28 with $N$-methylbenzylamine and, upon treatment with 2.5 equivalents of $\mathrm{BuLi} / \mathrm{KOBu}^{t}$, gave the aminoindole 22 (Scheme 7). There have been several reports of aminoindole formation by Gewald cyclisation of orthoaminobenzonitriles, ${ }^{10,11,29}$ and in the last case, involving cyclisation of an $\mathrm{N}$-benzyl group, it was noted that the 3-amino2-phenylindoles could not be isolated as such due to instability and they were instead directly acylated before isolation. This perhaps goes some way to explain the low yield obtained for 22 . The copper catalyzed cyclisation of 2-alkynylanilines with $O$ benzoylhydroxylamines also gives 3 -aminoindoles but is restricted to 3-dialkylamino products. ${ }^{16}$

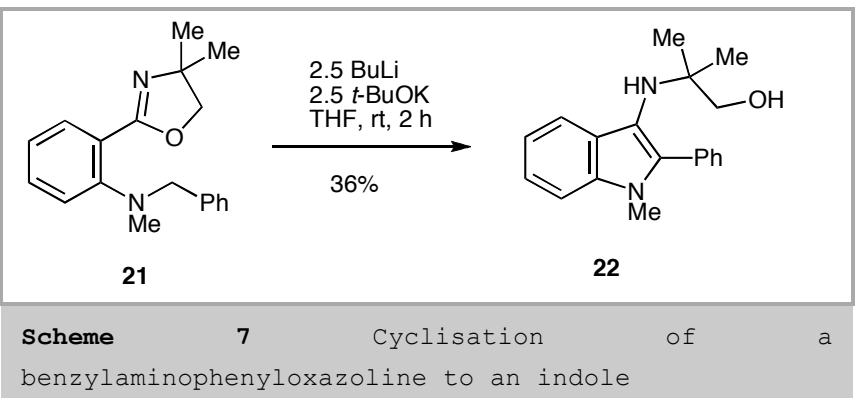

In summary we have developed a convenient new route to form 2-aryl-3-aminobenzofurans, also applicable to the corresponding benzothiophenes and indoles. Extension of the method to other fused ring heterocycles, such as various isomeric thienofurans, is currently being investigated and will be reported shortly.

\section{Funding Information}

We thank EPSRC (UK) for a DTA studentship (Grant No. EP/L505079/1) and the EPSRC UK National Mass Spectrometry Facility at Swansea University

\section{Supporting Information}

Full experimental procedures and spectroscopic data for all compounds, copies of ${ }^{1} \mathrm{H}$ and ${ }^{13} \mathrm{C}$ NMR spectra and details of X-ray structure for $\mathbf{1 6 .}$

\section{Primary Data}

(No)

\section{References and Notes}

(1) Reuman, M.; Meyers, A. I. Tetrahedron 1985, 41, 837.

(2) Gant, T. G.; Meyers, A. I. Tetrahedron 1994, 50, 2297.

(3) Meyers, A. I. J. Org. Chem. 2005, 70, 6137.

(4) Typical experimental procedures: A solution of 2-(benzyloxy)benzoic acid (10.00 g, $43.8 \mathrm{mmol}$ ) and thionyl chloride $(6.4 \mathrm{~mL}, 10.44 \mathrm{~g}, 87.7 \mathrm{mmol})$ in toluene $(90 \mathrm{~mL})$ was heated under reflux for $3 \mathrm{~h}$ and then cooled and evaporated to give 2-(benzyloxy)benzoyl chloride $(10.80 \mathrm{~g}, 100 \%)$ as a pale yellow oil which was used without further purification.

This was dissolved in $\mathrm{CH}_{2} \mathrm{Cl}_{2}(40 \mathrm{~mL})$ and added dropwise to a solution of 2-amino-2-methylpropan-1-ol (7.81 g, $87.6 \mathrm{mmol}$ ) in $\mathrm{CH}_{2} \mathrm{Cl}_{2}(50 \mathrm{~mL})$ stirred at $0{ }^{\circ} \mathrm{C}$. Once the addition was complete, the reaction mixture was allowed to warm to $\mathrm{rt}$ for $18 \mathrm{~h}$ before being poured into water. The two layers were separated and the aqueous layer was re-extracted with $\mathrm{CH}_{2} \mathrm{Cl}_{2}(\times 2)$. The combined organic layers were washed successively with $2 \mathrm{M} \mathrm{HCl}, 2 \mathrm{M} \mathrm{NaOH}$ and water before being dried and evaporated to give the amide (12.68 g, 97\%) as a colourless solid, mp $115-117{ }^{\circ} \mathrm{C}$, which was used without further purification.

Thionyl chloride (3.7 $\mathrm{mL}, 6.03 \mathrm{~g}, 50.7 \mathrm{mmol}$ ) was added to a solution of 2-(benzyloxy)- $N$-(1-hydroxy-2-methylpropan-2yl)benzamide (12.68 $\mathrm{g}, 42.4 \mathrm{mmol})$ in $\mathrm{CH}_{2} \mathrm{Cl}_{2}(210 \mathrm{~mL})$ and the reaction mixture was stirred at $\mathrm{rt}$ for $18 \mathrm{~h}$. The mixture was washed with $2 \mathrm{M} \mathrm{NaOH}$ and water before being dried and evaporated to give, after purification by Kugelrohr distillation (185 ${ }^{\circ} \mathrm{C} / 9.2$ Torr), 1 (10.14 g, 85\%) as a colourless oil which formed a low-melting solid on standing. IR: 1718, 1645, 1038, $967,871,848,751,733,695 \mathrm{~cm}^{-1} .{ }^{1} \mathrm{H}$ NMR (500 MHz): $\delta=7.72$ (dd, $J=7.5,2.0 \mathrm{~Hz}, 1 \mathrm{H}), 7.52$ (d, $J=7.5 \mathrm{~Hz}, 2 \mathrm{H}), 7.38-7.35(\mathrm{~m}, 3$ H), $7.29(\mathrm{t}, J=7.3 \mathrm{~Hz}, 1 \mathrm{H}), 7.01-6.97(\mathrm{~m}, 2 \mathrm{H}), 5.18(\mathrm{~s}, 2 \mathrm{H}$, $\mathrm{OCH}_{2} \mathrm{Ar}$ ), $4.11\left(\mathrm{~s}, 2 \mathrm{H}\right.$, oxazoline $\left.\mathrm{CH}_{2}\right), 1.41\left(\mathrm{~s}, 6 \mathrm{H}, \mathrm{CH}_{3}\right) .{ }^{13} \mathrm{C} \mathrm{NMR}$ (125 MHz): $\delta=161.2(\mathrm{C}=\mathrm{N}), 157.3(\mathrm{C}-0), 137.0(\mathrm{C}), 131.9(\mathrm{CH})$, $131.1(\mathrm{CH}), 128.2(2 \mathrm{CH}), 127.5(\mathrm{CH}), 126.7(2 \mathrm{CH}), 120.6(\mathrm{CH})$, $118.6(\mathrm{C}), 113.5(\mathrm{CH}), 78.8$ (oxazoline $\left.\mathrm{CH}_{2}\right), 70.5\left(\mathrm{OCH}_{2} \mathrm{Ar}\right), 67.5$ (C), $28.4\left(\mathrm{CH}_{3}\right)$. HRMS $\left(\mathrm{ESI}^{+}\right): \mathrm{m} / z$ calcd for $\mathrm{C}_{18} \mathrm{H}_{20} \mathrm{NO}_{2}[\mathrm{M}+\mathrm{H}]^{+}$: 282.1489; found: 282.1478 .

Under a nitrogen atmosphere, $n$-butyllithium $(2.5 \mathrm{M}$ in hexane, $6.6 \mathrm{~mL}, 16.5 \mathrm{mmol})$ was added to a stirred mixture of 2-(2(benzyloxy)phenyl)-4,4-dimethyl-4,5-dihydrooxazole 1 (1.41 g, $5.01 \mathrm{mmol}$ ) and potassium tert-butoxide (1.88 $\mathrm{g}, 16.8 \mathrm{mmol})$ in dry THF $(50 \mathrm{~mL})$. The reaction mixture was stirred at $\mathrm{rt}$ for $2 \mathrm{~h}$ before being quenched by addition of sat. aq. $\mathrm{NH}_{4} \mathrm{Cl}$ and extracted with $\mathrm{Et}_{2} \mathrm{O}(\times 3)$. The combined organic layers were dried and evaporated to give, after purification by column chromatography $\left(\mathrm{Al}_{2} \mathrm{O}_{3}\right.$, gradient elution, $\mathrm{Et}_{2} \mathrm{O} /$ hexane $3: 2$ to EtOAc), 3 (1.13 g, $80 \%)$ as orange crystals, mp $59-63{ }^{\circ} \mathrm{C}$. IR: $3325,2974,2933$, $1605,1452,1362,1256,1043,1026,739,694 \mathrm{~cm}^{-1} .{ }^{1} \mathrm{H}$ NMR $(400$ MHz): $\delta=8.08-8.05(\mathrm{~m}, 2 \mathrm{H}), 7.64-7.62(\mathrm{~m}, 1 \mathrm{H}), 7.46-7.41(\mathrm{~m}, 3$ $\mathrm{H})$, 7.34-7.30 (m, $1 \mathrm{H}), 7.29-7.25(\mathrm{~m}, 1 \mathrm{H}), 7.24-7.20(\mathrm{~m}, 1 \mathrm{H})$, $3.42\left(\mathrm{~s}, 2 \mathrm{H}, \mathrm{CH}_{2}\right), 2.65$ (br s, $2 \mathrm{H}, \mathrm{NH}$ and $\left.\mathrm{OH}\right), 1.07\left(\mathrm{~s}, 6 \mathrm{H}, \mathrm{CH}_{3}\right)$. ${ }^{13} \mathrm{C}$ NMR (125 MHz): $\delta=153.0(\mathrm{C}), 148.5$ (C), 131.1 (C), 129.5 (C), $128.5(2 \mathrm{CH}), 128.0(\mathrm{CH}), 126.5(2 \mathrm{CH}), 124.4(\mathrm{CH}), 122.5(\mathrm{CH})$, $122.2(\mathrm{C}), 119.6(\mathrm{CH}), 111.2(\mathrm{CH}), 70.3\left(\mathrm{CH}_{2}\right), 58.1(\mathrm{C}), 24.7\left(\mathrm{CH}_{3}\right)$. HRMS (ESI ${ }^{+}$): $m / z$ calcd for $\mathrm{C}_{18} \mathrm{H}_{20} \mathrm{NO}_{2}[\mathrm{M}+\mathrm{H}]^{+}:$282.1489; found: 282.1482.

(5) Baker, R. W.; Hockless, D. C. R.; Pocock, G. R.; Sargent, M. V.; Skelton, B. W.; Sobolev, A. N.; Twiss (née Stanojevic), E.; White, A. H. J. Chem. Soc., Perkin Trans. 1 1995, 2615.

(6) Yalcouye, B.; Berthelot-Bréhier, A.; Augros, D.; Panossian, A.; Choppin, S.; Chessé, M.; Colobert, F.; Leroux, F. R. Eur. J. Org. Chem. 2016, 725.

(7) Augros, D.; Yalcouye, B.; Berthelot-Bréhier, A.; Chessé, M.; Choppin, S.; Panossian, A.; Leroux, F. R. Tetrahedron 2016, 72, 5208.

(8) Gewald, K.; Jänsch, H.-J. J. Prakt. Chem. 1973, 315, 779.

(9) Sarodnick, G.; Kempter, G. E. Ger. Pat. DD292001, 1991; Chem. Abstr. 1991, 115, 232294.

(10) Radl, S.; Hezky, P.; Urbánková, J; Váchal, P.; Krejcí, I. Collect. Czech. Chem. Commun. 2000, 65, 280.

(11) Radl, S.; Obadalova, I. Arkivoc 2005, part xv, 4.

(12) Yang, J.; Wangweerawong, A.; Dudley, G. B. Heterocycles 2012, 85, 1603.

(13) Meyers, A. I.; Hanagan, M. A.; Trefonas, L. M.; Baker, R. J. Tetrahedron 1983, 39, 1991.

(14) Poindexter, G. S. J. Org. Chem. 1982, 47, 3787.

(15) Hirano, K.; Satoh, T.; Miura, M. Org. Lett. 2011, 13, 2395-2397. 
(16) Matsuda, N.; Hirano, K.; Satoh, T.; Miura, M. J. Org. Chem. 2012, 77, 617-625

(17) von Auwers, K. Ber. Dtsch. Chem. Ges. 1916, 49, 820.

(18) Feng, G.; Wu, J.; Dai, W.-M. Tetrahedron Lett. 2007, 48, 401.

(19) Raasch, M. S. J. Org. Chem. 1980, 45, 856.

(20) Crystal data for 16: $\mathrm{C}_{18} \mathrm{H}_{19} \mathrm{NOS}, \mathrm{M}=297.41$, colourless prism, crystal dimensions $0.20 \times 0.20 \times 0.20 \mathrm{~mm}$, monoclinic, space group P2 $1 /$ c, $a=11.976(2), b=12.4118(15), c=20.997(3) \AA ̊ ., \beta=$ $95.825(6)^{\circ}, V=3105.0(8) \AA^{3}, Z=8, D_{c}=1.272 \mathrm{Mg} \mathrm{m}^{-3}, T=173 \mathrm{~K}$, $R=0.0345, R_{W}=0.0801$ for 4529 reflections with $I>2 \sigma(I)$ and 395 variables. Data were collected using graphite monochromated Mo-K $\alpha$ radiation, $\lambda=0.71075 \AA$ and have been deposited at the Cambridge Crystallographic Data Centre as CCDC 1540330.
(21) Lee, T. D.; Keana, J. F. W. J. Org. Chem. 1976, 41, 3237.

(22) Beck, J. R. J. Heterocycl. Chem. 1978, 15, 513.

(23) Carrington, D. E. L.; Clarke, K.; Scrowston, R. M. J. Chem. Soc. (C) 1971, 3903.

(24) Beck, J. R. J. Org. Chem. 1972, 37, 3224.

(25) Beck, J. R.; Yahner, J. A. J. Org. Chem. 1974, 39, 3440

(26) Markert, J.; Hagen, H. Liebigs Ann. Chem. 1980, 768.

(27) Kobayashi, K.; Yamashita, K. Heterocycles 2017, 94, 772.

(28) Meyers, A. I.; Gabel, R.; Mihelich, E. D. J. Org. Chem. 1978, 43, 1372.

(29) Seong, C. M.; Park, C. M.; Choi, J.; Park, N. S. Tetrahedron Lett. 2009, 50, 1029. 